\title{
PENGOLAHAN CITRA DIGITAL UNTUK MENENTUKAN BOBOT SAPI MENGGUNAKAN METODE CANNY EDGE DETECTION
}

\author{
Ashari' $^{1}$, Nuraida Latif ${ }^{2}$, Ayu Astuti ${ }^{3}$ \\ Program Studi Teknik Informatika ${ }^{1,3}$ \\ Program Studi Teknik Komputer ${ }^{2}$ \\ STIMIK AKBA Makassar, Sulawesi Selatan \\ ashari@akba.ac.id,nuraida@akba.ac.id
}

\begin{abstract}
ABSTRAK
Penelitian ini bertujuan untuk mengimplementasikan sebuah Sistem Pengolahan Citra Digital menggunakan perangkat Android untuk menentukan bobot sapi secara praktis dengan menggunakan metode Canny edge detection. Data ini diperoleh dari studi pustaka, penelitian lapangan, dan wawancara . Hasil penelitian ini menunjukkan bahwa implementasi pengolahan citra untuk menghasilkan penentuan bobot sapi menggunakan rumus Schoorl, diperoleh rata - rata error yang dihasilkan adalah $7,176 \mathrm{~kg}$, dan rata - rata berat 10 ekor sapi tersebut adalah $185 \mathrm{~kg}$. Sehingga tingkat akurasi hasil penelitian adalah 50,258\%.
\end{abstract}

Kata Kunci: Canny Edge, OpenCV, Android , Pengolahan Citra Digital .

\begin{abstract}
The aims of the study is to implement a Digital Image Processing System using an Android device to determine the weight of cattle practically using the Canny edge detection method. This data is obtained from Literature Study, and Field Research interviews. The results of the study indicate that the implementation of image processing to produce the determination of cattle weight using the Schoorl formula. With an average error generated is 7.176 $\mathrm{kg}$, and the average weight of $10 \mathrm{cows}$ is $185 \mathrm{~kg}$. So that the level of accuracy of the research results is $50.258 \%$.
\end{abstract}

Keywords: Canny Edge Detection, OpenCV, Android, Digital Image Processing 


\section{PENDAHULUAN}

Perkembangan peternakan sapi di Indonesia secara umum masih sangat memprihatinkan. Sebagian besar produksi daging sapi di Indonesia hampir seluruhnya diperoleh dari peternakan rakyat (78\%). Sisanya dari impor, sekitar lima \% berupa daging sapi dan $17 \%$ ternak hidup (Soehadji, dalam Saleh et al. 2014).

Sapi merupakan komoditas utama penghasil daging yang dikonsumsi masyarakat. Kuantitas dan kualitas daging yang dihasilkan oleh sapi sangat berkaitan dengan berat badan sapi tersebut. Ukuran bobot badan merupakan salah satu indikator ekonomi yang penting dalam peternakan sapi potong. Bobot badan juga sangat berkaitan erat dengan aspek ekonomi lainnya meliputi produksi dan reproduksi. Pertumbuhan ternak umumnya dapat diukur dengan bertambahnya bobot badan sedangkan besarnya badan dapat diketahui dengan mengukur tinggi badan, panjang badan dan lingkar dada.

Perhitungan berat badan sapi dapat dilakukan dengan menggunakan alat timbang konvensional yang memiliki akurasi tinggi karena sapi ditimbang secara langsung. Namun alat timbang konvensional ini juga memiliki beberapa kekurangan yaitu tidak praktis dan harganya sangat mahal. Untuk peternak kecil dan beberapa pasar sapi tradisional, keberadaan alat timbang konvensional sangat susah untuk terpenuhi karena masalah harga. Dalam dunia peternakan dikenal cara pendugaan berat badan sapi dengan mengetahui ukuran bagian tertentu pada tubuh sapi. Metode yang dapat digunakan untuk menduga bobot badan adalah dengan hanya menaksir bobot badan ternak tersebut..

Bobot badan juga merupakan indikator penilaian produktivitas dan keberhasilan manajemen peternakan. Kendala yang umumnya terjadi dalam hal pendugaan bobot badan adalah tidak tersedianya alat ukur untuk menduga bobot badan ternak yang berkapasitas besar. Pendugaan bobot badan ternak menjadi hal yang sangat penting untuk diketahui, khususnya bagi peternak dan pedagang ternak sehingga tidak terjadi kecurangan yang dapat merugikan sebelah pihak, Untuk mengatasi masalah tersebut, dibutuhkan suatu solusi yang dapat menjadi alternatif keberadaan alat timbang konvensional.

\section{TINJAUAN PUSTAKA}

\section{$2.1 \quad$ Citra Digital}

Citra digital merupakan citra yang dihasilkan dari pengolahan dengan menggunakan komputer, dengan cara merepresentasikan citra secara numerik dengan nilai - nilai diskret. Pada umumnya citra digital berbentuk empat persegi panjang, dan dimensi ukurannya dinyatakan dalam tinggi kali lebar atau panjang kali lebar.

Sama halnya Proses digitalisasi dalam bentuk data lain, proses digitalisasi pada citra juga merupakan proses pengubahan suatu bentuk data citra dari yang bersifat analog ke digital. Yang mana proses ini dihasilkan dari peralatan digital yang langsung bisa diproses oleh komputer.

Berdasarkan bentuknya, Citra digital dapat dikelompokkan menjadi 4 jenis, yaitu:

a. Citra RGB (Red, Green, Blue). Untuk citra RGB masing-masing pixel mempunyai sebuah warna khusus. Warna dideskripsikan oleh kombinasi komponen warna merah (Red), hijau (Green) dan biru (Blue) masing-masing komponen warna mempunyai range antara 0255, sehingga total range warna yang digunakan untuk citra RGB adalah 16.777.216.

b. Citra abu-abu (Grayscale). Untuk citra abu-abu masing-masing pixel memiliki nilai normal 0 (hitam) sampai 255 (putih) yang dapat direpresentasikan oleh nilai 8 bit atau 1 byte.

c. Citra Biner. Setiap pixel hanya mempunyai warna hitam dan putih yang memiliki nilai 0 untuk hitam dan 1 untuk putih.

d. Indexed. Citra paling berwarna hanya memiliki sebagian kecil dari 16 juta kemungkinan warna. Untuk efisiensi storage dan kemudahan dalam handling file, sebuah gambar akan diasosiasikan dengan peta warna (color map) atau color pallete.

\subsection{Deteksi Tepi}

Tepi (edge) adalah perubahan nilai intensitas derajat keabuan yang cepat atau tiba-tiba (besar) dalam jarak yang singkat. Sedangkan deteksi tepi (Edge Detection) pada suatu citra adalah suatu proses yang menghasilkan tepi-tepi dari obyekobyek citra, tujuannya adalah untuk menandai bagian yang menjadi detail citra dan memperbaiki detail dari citra yang kabur, yang terjadi karena error atau adanya efek dari proses akuisisi citra.

\subsection{Canne Edge detection}

Metode canny merupakan salah satu algoritma deteksi tepi. Deteksi tepi Canny ditemukan oleh Marr dan Hildreth yang meneliti pemodelan persepsi visual manusia, kemudian dikembangkan oleh John F. Canny pada tahun 1986 dan menggunakan algoritma multi-tahap untuk mendeteksi berbagai tepi dalam gambar. Kelebihan dari metode Canny ini adalah kemampuan untuk mengurangi noise sebelum melakukan perhitungan deteksi tepi sehingga tepi-tepi yang dihasilkan lebih banyak.

Canny edge detection secara umum (detilnya tidak baku atau bisa divariasikan) beroperasi sebagai berikut:

1. Penghalusan Citra Biasanya teknik yang digunakan pada tahap ini adalah Gaussian Blur.

2. Menghitung Potensi Gradien Citra Gradien merupakan operator yang paling mendekati definisi dari sebuah edge.

3. Median blur adalah proses penghalusan citra dengan menggunakan median filter. Median 
filter sangat efektif untuk menghilangkan noise dan dapat mempertahankan detail citra karena tidak tergantung pada nilai-nilai yang berbeda dengan nilai-nilai yang umum dalam lingkungannya. Penggunaan media filter di tunjukkan pada gambar di berikut :

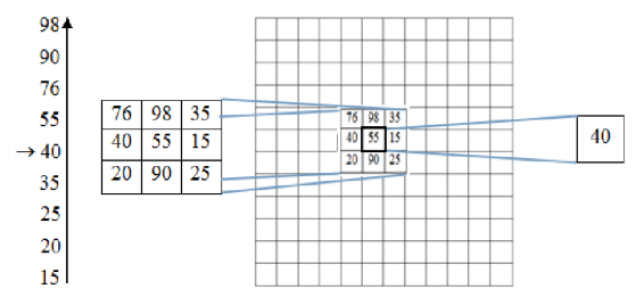

Gambar 2.1 Ilustrasi penggunaan median filter

\section{Sharp}

Merupakan proses penajaman citra dengan cara mengkonvolusi citra awal dengan cara mengalikan piksel citra awal dengan kernel sharp.

5. Rumus Penentuan Bobot Sapi.

Dalam penentuan bobot sapi, rumus yang sering digunakan adalah Rumus Schrool yang ditunjukkan pada persamaan 2.1

$$
\begin{aligned}
& \text { Berat Badan }=\frac{(L D+22)^{2}}{100} \\
& (2.1)
\end{aligned}
$$

Data yang diperlukan berupa lingkar dada dari sapi. Lingkar Dada (LD), diukur melingkar pada posisi di belakang tonjolan pundak sapi di bagian atas dan bagian belakang kaki depan. (Abidin, 2008).

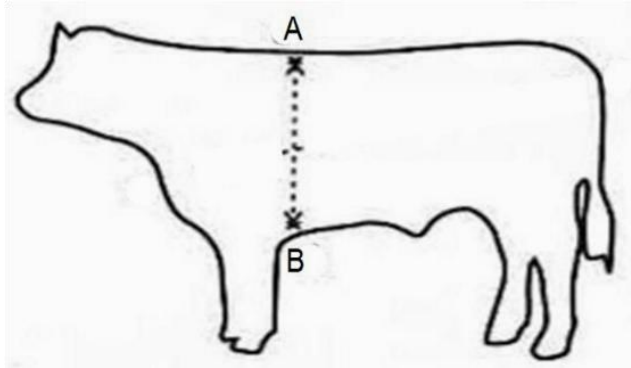

Gambar 2.5 Lingkar Dada Ternak sapi

6. Non-maximal Supression7 Non-maximal supression bertujuan membuang potensi gradien di suatu piksel dari kandidat edge jika piksel tersebut bukan merupakan maksimal lokal pada arah edge di posisi piksel tersebut (di sinilah arah gradien diperlukan).

7. Hysteresis Thresholding Hysteresis Thresholding adalah klasifikasi dengan dua buah nilai High-threshold dan Low-Threshold.

8. Proses Segmentasi Citra Segmentasi yaitu mereduksi citra menjadi objek atau region, misalnya memisahkan objek-objek yang berbeda dengan mengekstraksi batas-batas objek (boundary).

\section{METODE YANG DIUSULKAN}

\subsection{Teknik Pengumpulan Data}

Teknik pengumpulan data yang digunakan antara lain :

a. Observasi, yaitu mengumpulkan dan memperoleh data melalui pengamatan secara langsung di RPH (Rumah Pemotongan Hewan) Kota Makassar.

b. Wawancara, yaitu melakukan wawancara langsung dengan menggunakan daftar pertanyaan baik bersifat terbuka maupun tertutup.

c. Dokumentasi yaitu pengumpulan data, pengambilan gambar dilapangan, serta perolehan data sekunder dari instansi terkait

\subsection{Desain Model Sistem}

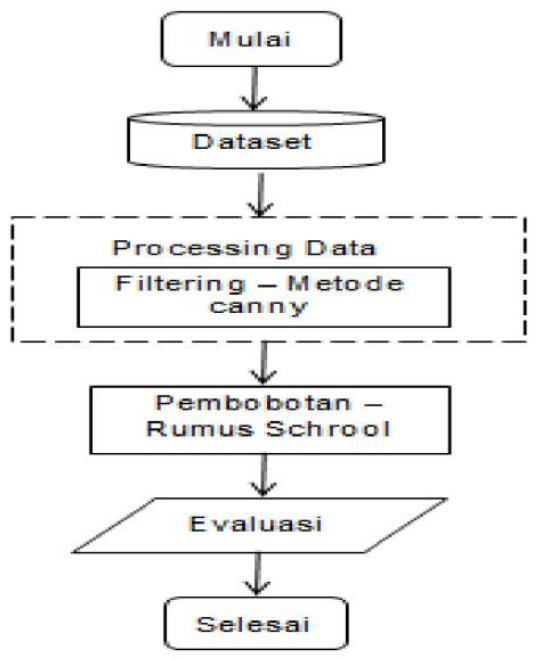

Gambar 3.2 Desain Model Sistem

\section{HASIL DAN PEMBAHASAN}

Cara kerja dari program aplikasi yang dibuat sebagai berikut :

\subsection{Form Utama}

Form utama merupakan tampilan awal dari aplikasi Menghitung Bobot Sapi. Pada halaman ini terdapat menu cari foto dan menu olah gambar. Form utama dapat dilihat pada gambar 4.1. 


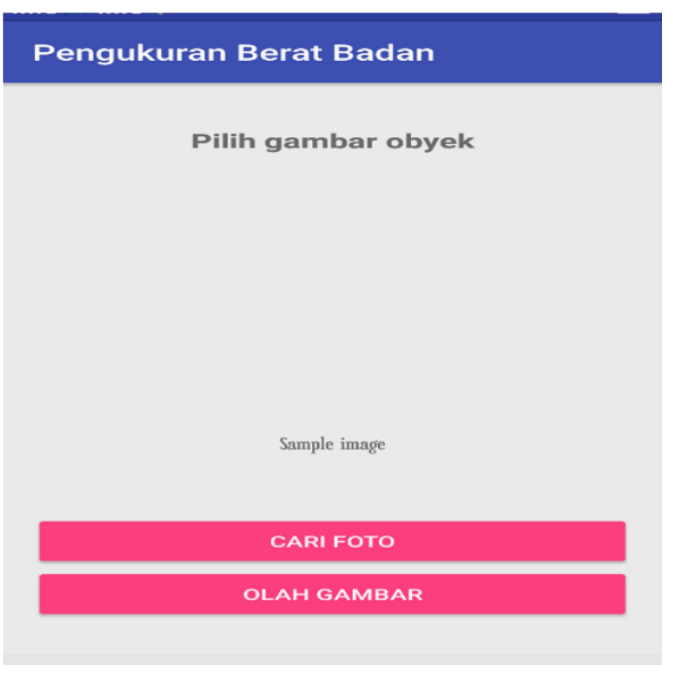

Gambar 4.1 form Utama

\subsection{Form Cari Foto}

Form cari foto merupakan Form yang akan ditampilkan pertama kali saat membuka aplikasi. Pada Form ini pengguna mencari foto sapi dari galeri handphone. Form cari foto dapat dilihat pada gambar 4.2

\section{Pengukuran Berat Badan}

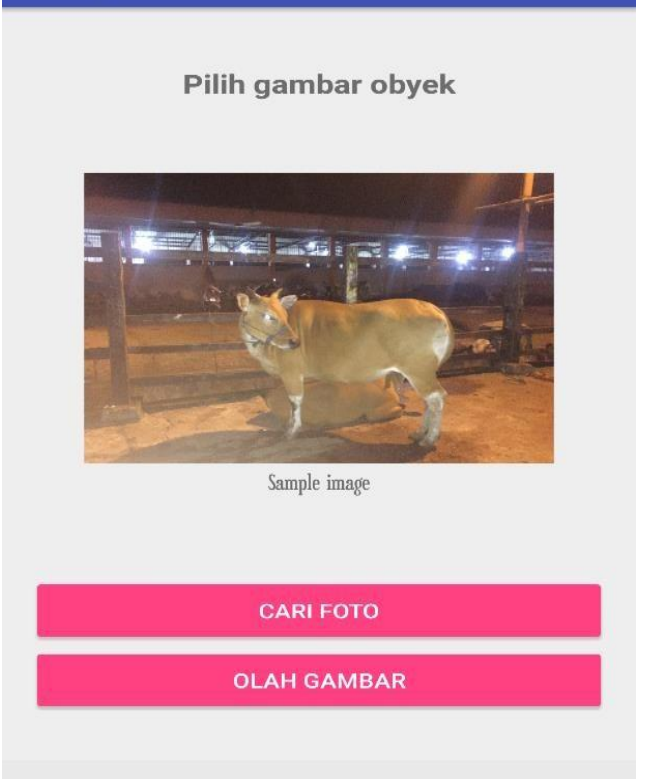

Gambar 4.2 Form cari foto

\subsection{Form Olah Gambar}

Form olah gambar merupakan form yang menampilkan hasil gambar sapi yang telah diolah menjadi citra canny edge. Tampilan form olah gambar dapat dilihat dari gambar 4.3.
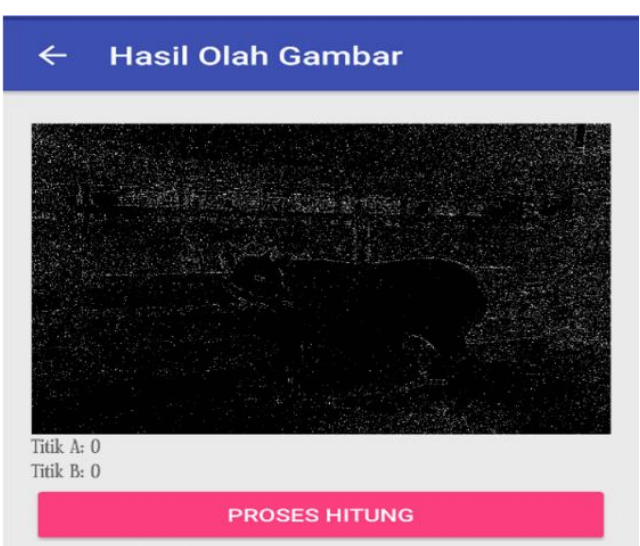

Berat (Kg): 0

Gambar 4.3 Form Olah Gambar

Setelah gambar sapi diolah menjadi citra canny edge proses selanjutnya menentukan titik A dan titik B dengan menyentuh citra canny edge pada bagian tepi atas (punggung sapi) dan tepi bawah (perut sapi) pastikan Titik A dan Titik B tidak berupa angka 0, lalu klik tombol proses hitung. Hasil hitung bobot sapi dapat dilihat pada gambar 4.4.

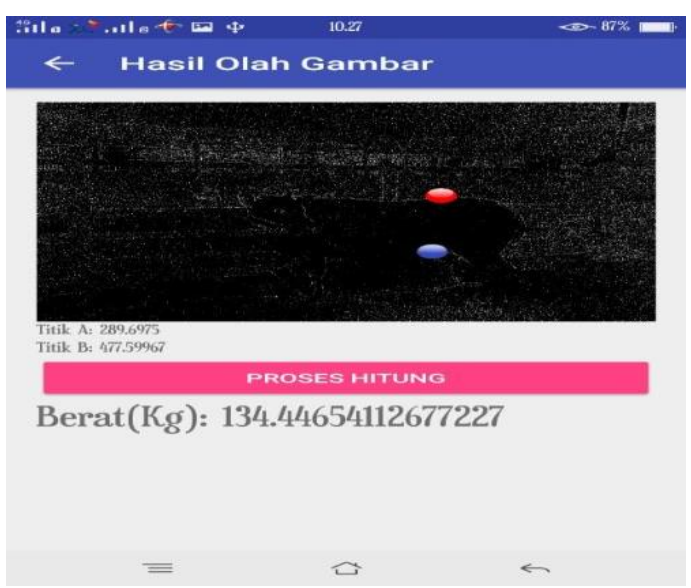

Gambar 4.4 form proses hitung

Berikut evaluasi perbandingan bobot sapi sebenrnya dengan bobot sapi hasil pengolahan menggunakan sistem aplikasi dapat dilihat pada tabel 4.5 
Tabel 4.5 Tabel perbandingan bobot sapi sebenarnya dan bobot sapi menggunakan system
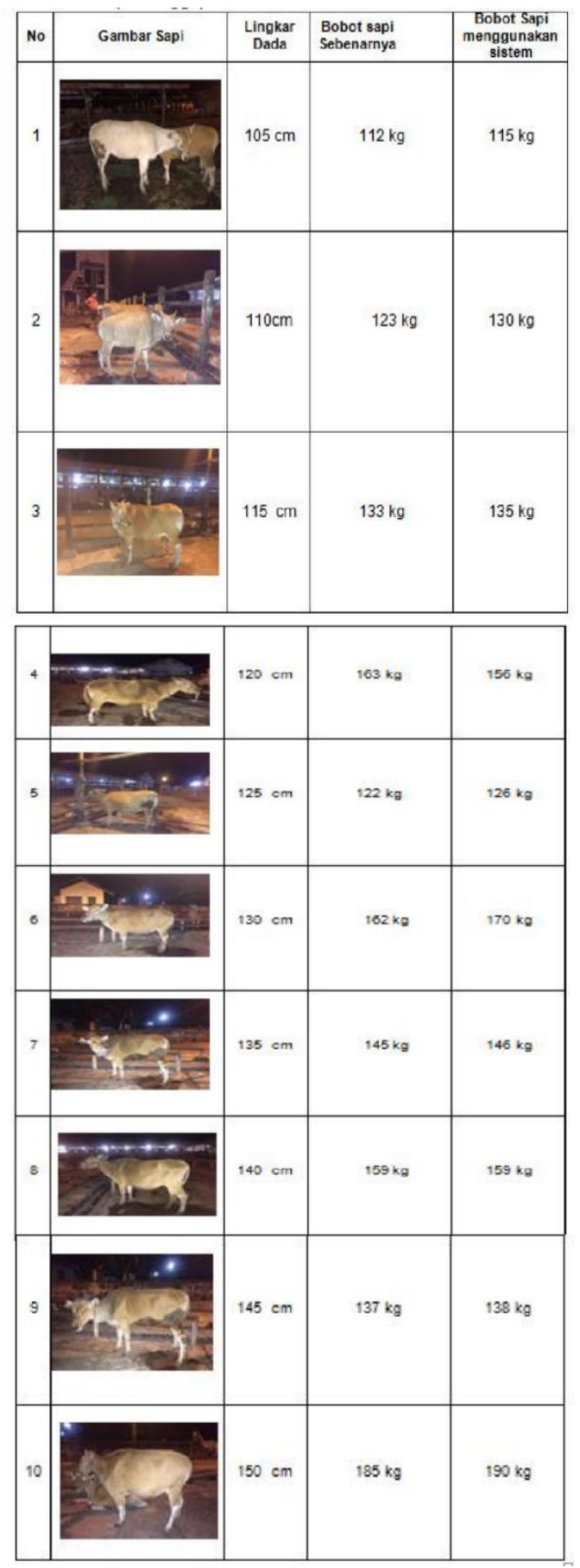

Dari tabel 4.5, dapat diketahui hasil perhitungan akurasi dan margin error-nya. Rata rata error yang dihasilkan adalah $7,176 \mathrm{~kg}$, dan rata - rata berat 10 ekor sapi tersebut adalah $185 \mathrm{~kg}$ maka didapatkan data sebagai berikut:

$$
\begin{aligned}
& \text { Error }(\%)=\frac{\text { Rata-rata Error }}{\text { Rata-rata BB Sapi }} \times 100 \% \\
& \text { Error }(\%)=\frac{7,176 \mathrm{~kg}}{185 \mathrm{~kg}} \times 100 \% \\
& \operatorname{Error}(\%)=0,378 \%
\end{aligned}
$$

Dari hasil perhitungan margin error di atas, dapat diketahui pula akurasi hasil penelitian dengan perhitungan sebagai berikut:

$$
\begin{aligned}
& \text { Akurasi }(\%)=100 \%-\operatorname{Error}(\%) \\
& \text { Akurasi }(\%)=100 \%-0.378(\%)
\end{aligned}
$$

\section{KESIMPULAN}

Berdasarkan hasil analisis yang didapatkan maka dapat diambil beberapa kesimpulan :

1. Aplikasi pengolahan citra digital dapat diketahui bobot sapi menggunakan canny edge detection dengan menggunakan variabel lingkar dada pada obyek sapi.

2. Penentuan bobot sapi menggunakan rumus Schoorl, diperoleh rata - rata error yang dihasilkan adalah $7,176 \mathrm{~kg}$, dan rata - rata berat 10 ekor sapi tersebut adalah $185 \mathrm{~kg}$. Sehingga tingkat akurasi hasil penelitian adalah $50,258 \%$.

\section{DAFTAR PUSTAKA}

[1] Ahmad Mustafid dan Shofwatul Uyun . 2017 Segmentasi Citra Sapi Berbasis Deteksi Tepi Menggunakan Algoritma Canny Edge Detection. Yogyakarta : Teknik Informatika, Fakultas Sains dan Teknologi, UIN Sunan Kalijaga

[2] Basuki, Achmad. 2005. Metode Numerik dan Algoritma Komputasi. Yogyakarta: ANDI.

[3] Kusumadewi , Sri . 2003 . Artifical Intelligence (teknik dan Aplikasinya) . Yogyakarta . Penerbit Graha Ilmu

[4] Linda Herliani Harefa . 2016 . Analisis Edge Detection Citra Digital Dengan Menggunakan Metode Robert Dan Canny. Medan : Teknik Informatika STMIK Budi Darma Medan.

[5] Lazuardi Arsy, Kurniawan Teguh Marton. 2016. Aplikasi Pengolahan Citra Digital Meat Detection Dengan Metode Segmentasi K-Mean Clustering Berbasis OpenCV Dan Eclipse. Diponegoro : Fakultas Teknik 
[6] Mahmud Yunus . 2015 . Perbandingan Metode-Metode Edge Detection Untuk Proses Segmentasi Citra Digital . Malang . Program Studi Teknik Informatika

[7] Mazid Kamal, Ruri Suko Basuki. 2007. Segmentasi Citra Daun Tembakau Berbasis Deteksi Tepi Menggunakan Algoritma Canny. Semarang .Teknik Informatika Universitas Dian Nuswantoro

[8] Rosa dan M. Shalahuddin. 2013. Rekayasa Perangkat Lunak. Bandung.

[9] Riyanto Aris, dkk. 2016. Perancangan Aplikasi Pendugaan Berat Badan Sapi dengan Memanfaatkan Kamera pada Smartphone Berbasis Android. Semarang : Sistem Komputer, Fakultas Teknik, Universitas Diponegoro.

[10] Satrio Firmansyah, Danang Lelono, Raden Sumiharto. $2015 . \quad$ Implementasi Pengolahan Citra Digital Sebagai Pengukur Nilai Resistor Pada Sistem Pemindai Resistor Berbasis Android. Elektronika dan Instrumentasi Jurusan Ilmu Komputer dan Elektronika

[11] St. Nur Ramadhani. 2015. Tingkat Pemotongan Dan Berat Daging Sapi Bali Berdasarkan Jenis Kelamin Dan Umur Ternak. Makassar : Fakultas Peternakan Universitas Hasanuddin Makassar

[12] Safaat, Nazruddin. 2012 . Pemograman Aplikasi Mobile Smartphone dan Tablet PC Berbasis Android . Bandung. Tehnik Informatika .

[13] Zakiah, Amiruddin Saleh, Krishnarini Matindas. 2017. Gaya Kepemimpinan dan Perilaku Komunikasi GPPT dengan Kapasitas Kelembagaan. Program Studi Komunikasi Pembangunan Pertanian dan Pedesaan IPB Sekolah Peternakan Rakyat di Kabupaten Muara Enim. Program Studi Komunikasi Pembangunan Pertanian dan Pedesaan IPB 